\section{Activities in the Context of a Network, Trust and Internal Resources as Antecedents of the Effectiveness of Network Governance: a Study of the Impact on the Performance of the Companies Involved}

\author{
Henrique Cordeiro Martins ${ }^{1, *}$ (1) \\ ${ }^{1}$ Universidade FUMEC, Belo Horizonte, MG, Brazil \\ Lucas Araújo Bassalo de Siqueira ${ }^{1, \dagger}$ (1) \\ ${ }^{1}$ Universidade FUMEC, Belo Horizonte, MG, Brazil \\ José Antônio Sousa $\mathrm{Neto}^{2}, \Omega$ (]) \\ ${ }^{2}$ Fundação Cultural Dr. Pedro Leopoldo, Pedro Leopoldo, MG, Brazil
}

\begin{abstract}
In a competitive business environment, the role of entities capable of exercising network governance $(\mathrm{NG})$ has become indispensable to the operations of the companies involved. With few theories that approach the subject, this work has as its main objective the investigation of the background of network performance, trust and internal resources in the effectiveness of the NG, and its influence on the performance of the companies. To this end, 181 companies linked to the FIEMG-MG were surveyed in a quantitative and descriptive analysis in which multivariate statistical analysis was used to analyse the data. The results show that, on one hand, there is significant and positive influence of reliable records and internal resources on the NG, and on the other, working in networks does not seem to have much relevance. It emphasizes that, together, the antecedents can explain about $75 \%$ of the variability of NG. The positive influence of NG on the performance of the companies involved could also be seen.
\end{abstract}

\section{KEYWORDS}

Network Governance, Network. Resources, Trust, Performance

FINANCIAL SUPPORT

FAPEMIG, Project CHE-PPM-00258-15
CORRESPONDING AUTHOR

${ }^{*}$ Henrique Cordeiro Martins Email: henrique.martins@fumec.br

†Lucas Araújo Bassalo de Siqueira Email: lucasbassalo@yahoo.com.br

${ }^{\Omega}$ José Antônio Sousa Neto Email: ja.hon@hotmail.com

Received: 14/11/2017.

Revised: 14/03/2018.

Accepted: 12/11/2018.

Published Online: 25/07/2019.

DOI: http://dx.doi.org/10.15728/bbr.2019.16.5.2 


\section{INTRODUCTION}

The business environment is becoming increasingly competitive and dynamic and this reinforces the need for a new form of competition between companies, based on the rapid transformation of knowledge into technologies and the vigorous dispute for competitive advantages (Guimarães, Almeida, Santos, \& Zaccarelli, 2007; Zaccarelli, Guimarães, Almeida, \& Almeida, 2007; Miles \& Snow, 1986; Guimarães, 2010). Child (2005) believes that one of the consequences of globalization is an increase in the integration processes between countries, companies and institutions, producing new forms of networked working.

This process of change that has been occurring over recent decades has led, therefore, to the appearance of new strategic partnerships and alliances (Child, 2005; Dutra, 2009), where risk sharing, bringing together complementary competences, economies of productive scale, and even access to new markets stand out (Dutra, 2009).

In this way, companies interested in participating in this process of cooperation should be willing to ally themselves with others, acting jointly and in a complementary fashion, forming groupings capable of aggregating value at the different levels of the productive chain (Guimarães, 2013). According to Dutra (2009), it is the desire to obtain gains in competitiveness that motivates companies to seek out activity in networks subject to the command of their governance.

In this sense, Zaccarelli, Telles, Siqueira, Boaventura and Donaire (2008) stress that the network governance (NG) entities have a central role to play in the operation of these groups, as they are capable of influencing behaviour and orientating strategies. The formulation of directives capable of maintaining the unity of the group is their responsibility, and in this way all the members can continue benefiting from the advantages obtained (Guimarães, 2013).

It can be stated therefore that network governance is influenced by different factors that interfere directly in the performance of these groupings, making them more or less competitive. One of these factors is promoting activity in a network context. This is fully discussed in the literature on governance. According to Ansell, Sondorp and Stevens (2012), networks are seen as an attractive element for governance, as they deal with various types of conflict.

One fundamental role for governance is to monitor the behaviour of management and guarantee the increase of company competitiveness, as they (companies) are inserted in a micro- environment of uncertainties. In this way it is vital to consider trust necessary among the companies of the grouping. For Zaheer, McEvily and Perrone (2003), this trust can be explained as a relationship to accept existing vulnerabilities based on positive expectations and intentions in behaviour, in other words, based on the engagement of the companies.

Finally, one must consider the importance of the internal resources of the company, such as specialization and know-how. So that, as stated by Roth, Wegner, Antunes Júnior and Padula (2012), it is indispensable for the managers to be able to offer efficient services that can improve the performance of companies present in the grouping.

Nevertheless, governance in groupings is approached in different ways. All of them, however, present similar characteristics and, because of this, are recognized and treated in this work as types of network governances. For Zaccarelli et al. (2008), this type of entity is formed by companies that, in establishing a relationship, form a system, which acquires its own particular characteristics, and thereby competitive differentials in relation to those that act in isolation. Guimarães (2010) reinforces this idea in affirming that the networking entities, a necessary means of acquiring Network Governance are, also, identified in the literature with the name of business networks or, also, simply networks. 
Thus, in this work we propose that the antecedent activities in a network, trust, and internal resources influence the effectiveness of this Network Governance entity, which, in its turn, increases the competitiveness of the grouping.

With this background, the research question orienting this work is: which of the antecedentsnetwork activities, trust, and internal resources - most influences the effectiveness of the Network Governance of the Federation of Industries of the State of Minas Gerais and how does this affect the performance of the companies involved?

In this sense, the objective of this article is to evaluate the antecedents of the effectiveness of the Network Governance of the Federation of Industries of the State of Minas Gerais and its influence on the performance of the group of companies. More specifically, the objectives were to check the influence of the antecedents of networking activities, trust and internal resources on the effectiveness of the Network Governance; and to check the impact of the Network Governance on the performance of the companies involved.

The choice of the Federation of Industries of the State of Minas Gerais for the analysis of this article is justified by the economic and social importance of this institution, as well as by the wide scope of its work, by its decades-long experience and by its wide-ranging presence in the state of Minas Gerais, Brazil.

Guimarães (2010) points out that it was necessary for new forms of governance to emerge in addition to those traditionally studied. This new model would focus on collective activities affecting all the companies belonging to a determined group, which would be capable of influencing the strategic decisions collectively. Thus, studies such as that of Zaccarelli et al. (2008), Guimarães (2013), Zaccarelli et al. (2007) and Roth et al. (2012) attempt to build theoretical constructs around the utilization of governance in groups of companies as tools for increasing competitiveness, as well as for conceptualizing and distinguishing the different types of governance. Other authors like Boaventura and Siqueira (2008), Dutra (2009), Zaccarelli and Santos (2008), and Gameiro (2008) focus on the question of the strategic formulation of the networks and in what way this choice can influence the increase of competitiveness.

It should be noted that the various studies in the area demonstrate only a theoretical conceptualization of a theme that is quite recent, while indicating the importance of governance mechanisms as instruments for the generation of competitive advantages for a business network. This study appears, therefore, with the purpose of strengthening the theoretical construction of the theme, by attempting to list some antecedents necessary for the effective establishment of network governance and its influence on the performance of the companies involved.

This being the case, this research intends to contribute to increasing and strengthening the knowledge in the network governance area, attempting to fill a gap observed in the literature with its dearth of studies that deal with the elements necessary for the establishment of good NG, and its influences.

In addition to this introduction, this article presents the theoretical references that support the arguments, the hypothetical research model, the methodology utilized, the analysis of the results, and the final considerations.

\section{THEORETICAL REFERENCES}

\subsection{Networking ENTITIES}

The increase of competitiveness of groupings organized in the form of clusters or networks (Castells, 1999) confirm the central role of network governance entities that are organized in 
these arrangements, and that are capable of influencing the behaviour and guiding the strategies of the companies in these groupings (Zaccarelli et al., 2008).

For Zaccarelli et al. (2008), networking systems are abstract entities, as they possess no owner, legal personality or organization chart. Thus, the authors further detect that the owners of the companies would point to this situation as absurd, as the final decisions fall exclusively to them. Nevertheless, it is necessary to produce an explanation for the capacity of these network entities to develop and compete without a hierarchical command structure. To this end, the authors state that it is indispensable to consider the mechanisms linked to self-organization and network governance that, although they assist in the evolution of these entities, are distinct processes (Guimarães, 2013; Zaccarelli et al., 2008).

One of the responsibilities of these networking entities is to formulate directives capable of maintaining the group of companies cooperating and benefiting from the competitive advantages these groupings provide (Guimarães et al., 2007; Guimarães, 2013) and, according to Zaccarelli et al. (2008) and Dutra (2009), are capable of confirming the existence and the importance of Network Governance.

For Guimarães (2013), in analysing the networking entities to understand their characteristics, in the first place one must keep in mind the competitive power of the grouping as the main element of reference. In this sense, studies prove that Network Governance is capable of influencing the strategic behaviour of the companies installed in networking entities (Zaccarelli et al., 2008; Guimarães, 2013; Dutra, 2009).

This being the case, starting from the presupposition that networking entities arise to increase the competitiveness of the group of companies involved in them, one must discuss the ways in which this competitiveness is attained (Guimarães et al., 2007).

From this point on, Zaccarelli et al. (2008) highlight the central role of Network Governance entities in the operation of these groupings, as they are capable of influencing behaviours and guiding strategies; given that, "one of the responsibilities of these entities [...] is to formulate the directives that maintain the group of companies, cooperating and benefiting from the competitive advantages of the clusters and the networks" (Guimarães, 2013, p. 02).

\subsection{NeTwOrK GovernanCE}

Network Governance is one of the new aspects that has arisen out of studies on corporate governance (Martins, Hildebrand, \& Ziviani, 2008). Even with its peculiarities, which will be dealt with later on, it attempts, as do the other forms of governance, to increase competitiveness and company performance, starting from the presupposition that at some moment in the relationship between them there will be conflicting situations arising out of private interests (Fittipaldi \& Donaire, 2007). The main difference with corporate governance is, therefore, the fact that the actors governed are companies, not individuals (Roth et al., 2012).

In considering, therefore, the theoretical framework of the studies of inter-organizational networks, the term governance may be used from two distinct perspectives (Roth et al., 2012). According to Roth et al. (2012), the first of these is used by Williamson (1991) and is considered an alternative to govern economic activities. Jones, Hesterly and Borgatti (1997) follow the same perspective and follow the same perspective and, in their analysis, discovered that the best conditions for the formation of networks was when they could obtain a larger competitive advantage by forming. The second perspective pointed out by Roth et al. (2012) is the structures and elements necessary to the internal coordination of the networks that have as their principal expounders Provan and Kenis (2008), who, in their work, attempt to demonstrate the central role of governance in the network and its impact on the effectiveness of the grouping. 
Although these entities do not have governance as a legal imperative, the fact of carrying out complex interactions means that a large number of activities indispensable to obtaining competitive advantages are not feasible without it (Zaccarelli et al., 2008; Roth et al., 2012), which has increased the importance of utilizing Network Governance (Jones, Hersterly, \& Borgatti, 1997).

This type of governance is characterized by a veiled, discreet, operation orientated to decisions of impact on competitiveness and on the result of the business grouping as a whole (Zaccarelli et al., 2008).

However, in spite of networks having been fully studied, little attention has been given to the role of governance (Provan $\&$ Kenis, 2008). The authors and the debates on this theme are still few, which, in part, accounts for the lack of clear definition, a general theory or, even, uniformity in the utilization of terms defining Network Governance. Among those who have adventured into this sphere, Zaccarelli et al. (2008) is noteworthy, for attempting to build explicative theories on the definition, existence and importance of the clusters and the business networks and on the way they are generated. Other authors have attempted to demonstrate both the utilization of Network Governance as a tool for increasing competitiveness empirically or conceptually (Fittipaldi \& Donaire, 2007; Dutra, 2009; Jones, Hesterly, \& Borgatti, 1997; Ebers \& Jarillo, 1997) and its influence on the results obtained (Guimarães et al., 2007; Guimarães, 2013). Provan and Kenis (2008) and Roth et al. (2012), on the other hand, are not concerned with the instruments utilized in the good functioning of the entities, but on the analysis of who is responsible for the grouping's governance.

It is understood that NG can be organized from three different perspectives (Provan $\&$ Kenis, 2008; Roth et al., 2012). The first and simplest of the models is that of shared governance, in which the companies work collectively as a network, but without a formal and exclusive administrative structure, supporting themselves exclusively on involvement and collective commitment (Provan $\&$ Kenis, 2008; Roth et al., 2012). While in the shared model, the role of governance is attributed to the whole network, the second model, called the Leading Organization, all the activities and key decisions are made by one only corporation, making these networks highly centralized and with high power asymmetry (Provan $\&$ Kenis, 2008). Finally, the third and last model, as Provan and Kenis (2008), point out, is that of the Network Administrative Organization (NAO). According to the authors, this system, is the creation of a separate administrative entity to govern the network and its activities.

Network Governance is characterized by complex interactions and decisions, (Klijn, Edelenbos, $\&$ Steijn, 2010) and, for this reason, another important aspect that can contribute to an increase in the performance of companies involved in a networking entity is the trust that should exist between the members. Morgan and Hunt (1994) propose that trust is important to preserve the relationships and cooperation, avoiding short term alternatives and opportunistic behaviour. In addition, for Dyer and Singh (1998), more acquaintance of the partners and reciprocity can increase the relationship of trust and, consequently, lead to a reduction in transaction costs.

Finally, one has to consider the importance of internal resources, perhaps with the building of specific assets, such as the joint development of labour and know-how (Dyer \& Singh, 1998). This results in the companies being able to obtain competitive advantages, and become more efficient, in this way increasing the performance of the companies in the group (Roth et al., 2012).

In this sense, the elements of Network Activities, Internal Resources and Trust were considered as antecedent elements necessary for the effectiveness of Network Governance. 


\subsection{Elements Influencing Network Governance}

Several works, by different authors in many sectors, have succeeded in demonstrating the existence of networking entities and of NG. These include Fittipaldi and Donaire (2007) for the magazine publishing sector; Guimarães et al. (2013), in the wine sector; Klijn, Edelenbos and Steijn (2010), in environmental projects; Ansell, Sondorp and Stevens (2012), in the health sector, in addition to other studies in the semiconductor, electronic, automobile, biotechnology, cinema, fashion industries, and, the case which is most highlighted in the literature on the theme, the Italian industrial districts (Zaccarelli et al., 2008; Jones, Hesterly, \& Borgatti, 1997; Ebers \& Jarillo, 1997).

Throughout the literature, it is clear that even if the networks have been studied from different perspectives, few studies highlight the role played by governance in these groupings (Provan \& Kenis, 2008).

Networking activities: business networks are not a new phenomenon, in fact they go back to the $17^{\text {th }}$ century. However, it is only recently, in a scenario characterized by high competition among companies, that an increasing number of managers have started to contemplate these new forms of cooperation (Hitt, Ireland, \& Hoskisson, 2003; Boaventura \& Siqueira, 2008; Balestrin, Verschoore, \& Perucia, 2011), held to be alternatives to competitive relational strategies (Astley, 1984). This amounted to the perception that, in determined conditions, companies formed a type of system with a greater capacity to compete and grow, compared to others outside it.

This change culminated in the production of numerous works within the theoretical framework used to deal with horizontalized networks as forms of activity for networking entities as in Fittipaldi and Donaire (2007), in the study focused on the magazine publishing sector; Guimarães et al. (2013), in the wine sector in the regions of Oporto in Portugal and in the Vale dos Vinhedos in the Brazilian Serra Gaúcha; Klijn, Edelenbos and Steijn (2010), in environmental products in the Netherlands; Ansell, Sondorp and Stevens (2012), in the health sector, in addition to other studies in the semiconductor, electronic, automobile, biotechnology, cinema, fashion industries and, in the case with greater projection in the literature on the theme, the Italian industrial districts (Zaccarelli et al., 2008; Jones, Hesterly, \& Borgatti, 1997; Ebers \& Jarillo, 1997).

Business networks, like the clusters, are, therefore, arrangements comprising different businesses that, to some degree, maintain ties of relationship among themselves to produce competitive gains, having as differentials the exchanges and the integration on the part of the networks and the geographical proximity of the clusters (Guimarães et al., 2007; Zaccarelli et al., 2008; Telles, 2008).

In this way, as activities in a network may produce competitive gains and NG only occurs in business groupings, it is natural that one can consider the idea of activities in a network as an influencing factor in the construction of effective NG.

Trust: the second factor that can contribute to the effectiveness of the NG, which will be considered in this article, is trust. This is a theme that has generated increasing interest in organizational studies, and its importance has been studied in various areas, such as leadership, management by objectives, negotiation and performance evaluation (Mayer, Davis, \& Schoorman, 1995). Its role as an essential component in cooperation among organizations should further be stressed, being one of the elements most utilized by managers that are active in networks (Child, Faulkner, \& Tallman, 2005).

Nevertheless, in spite of the significant number of studies that point out the importance of trust, few of them deal with the field of network governance and its impact on the search for results (Klijn, Edelenbos, \& Steijn, 2010). Mayer, Davis and Schoorman (1995) also mention 
the difficulty in studying it in organizations, due to factors such as the lack of a clear conceptual definition for it, the difficulty in defining the relationship between risk and trust and the confusion regarding its antecedents and consequents.

Trust can be considered the central mechanism capable of taking efficiency and coordination to the control of expectations and interactions among the parties (McEvily, Perrone, \& Zaheer, 2003), without which it would not be possible to attain the proposed objectives of the network. Trusting partners more tends to generate economic gains for everyone (Child, Faulkner, \& Tallman, 2005) being considered a mechanism for cost reduction and increase in company performance.

In view of what has been set out, the role of trust as a key element is clear not only for collaboration in business relationships (Claro \& Claro, 2004), but also for the success and development of cooperative arrangements (Child, Faulkner, \& Tallman, 2005). It is a fundamental element for obtaining competitive advantages through the reduction of conflicts and avoiding opportunistic behaviour in networking entities (Klijn, Edelenbos, \& Steijn, 2010; Claro \& Claro, 2004; Zaheer, Mcevily, \& Perrone, 1998; Maciel, Reinert, \& Camargo, 2011; Mayer, Davis, \& Schoorman, 1995; Morgan \& Hunt, 1994).

Internal resources: another relevant factor that can be considered for the building of the model were internal resources. In this sense, it is believed that the Resource Based View (RBV) deserves special attention from researchers, because it adopts as focus of analysis the internal questions relative to the structure of the industry that may be capable of better explaining the success or failure of the organizations (Carneiro, Cavalcanti, \& Silva, 1999). The RBV presupposes that organizations are possessors not of products, but of various resources (Wernerfelt, 1984), and it is through the utilization of these resources that companies succeed, in fact, in obtaining competitive advantages (Barney, 1991; Barney, Wright, \& Ketchen Jr., 2001).

One can consider, therefore, that the Resource Based View attempts to explain why some companies have a superior performance to others, utilizing the resources and tangible or intangible internal capacities as a strategy for standing out (Barney, 1991; Barney, Wright, \& Ketchen Jr., 2001).

The idea of the utilization of the network structure as a resource starts from the principle that the structural standard of the relationship of firms is something unique and has the potential to offer competitive advantages to its members (Gulati, Nohria, \& Zaheer, 2000). According to Gulati, Nohria and Zaheer (2000), recently, a large number of researchers have approached different aspects of business networks and their relationship with performance from the perspective of the RBV, which Gulati (1999) called "Resource Networks".

Thus, it is believed that the internal resources of the networking entity may be pointed to as being capable of positively influencing the effectiveness of Network Governance.

\subsection{Organizational Performance}

Organizational performance is a theme that has received considerable attention in conceptual and empirical studies (Carneiro et al., 2005), although the authors mention that, in spite of, or because of several works pointing out the factors that affect performance or its measurement, a consensus still has not been reached over how to characterize the construct or measure it.

Venkatraman and Ramanujam (1986), in the conceptualization of the theme, have already mentioned the importance of the theme and the difficulty in definition. They proposed that one of the factors in the difficulty of definition is in the treatment given by the field of strategic theory to performance, which analyses it from different perspectives. The authors point out two main aspects of the construct: the financial, that covers questions such as profitability, growth and market value, and the operational aspect, related to questions such as quality, customer 
satisfaction, innovation and reputation. So that Carneiro et al. (2005) point to the challenge of organizing these different perspectives in a consistent and integrated work.

In this sense, according to Barney (1991), several definitions for organizational performance have been proposed, but still no consensus has been formed on the meaning or criteria for attaining a better result, as each measure of performance has its pros and cons. Thus, he states that the best and most adequate form of achieving quality in the analysis is through the multiplicity of measures. To this end, Barney (1991) points to four planes for the analysis of organizational performance (a) Survival; (b) Countable Measures; (c) Multiple Stakeholders Perspective; (d) Measures of Present Value. Other authors, such as Venkatraman and Ramanujam (1986), in comparing financial and operational indicators, also propose the use of multiple measures for the definition of organizational performance.

It can be said, therefore, that organizational performance is "[...] Understood as a set of results that the organization is achieving as its activities are performed” (Ricci, 2010, p. 53). The measurement of performance, in its turn, is a crucial point for guaranteeing better yield for organizations, and can be defined in several ways and understood in various manners (Ricci, 2010).

\subsection{Theoretical Contributions to the Research Model}

The review of the literature has approached fundamental concepts on the research model that guides this whole work, contributing to the identification of their various measurable quantities and the definition of the theoretical model (Figure 1), in addition to the formulation of hypotheses. Chart 1 presents the variables and the reference authors who compose the constructs:

Nevertheless, the main source for the construction of this model started from the idea that even if networks have been studied from different perspectives, few studies have brought out the role played by governance in these groupings (Provan \& Kenis, 2008), and consequently no model or questionnaire has been structured to enable distinct variables to be measured.

Chart 1

Supporting References for the Variables of the Constructs

\begin{tabular}{|c|c|c|}
\hline Construct & Hypothesis & Authors \\
\hline Network Activities & $\mathrm{H} 1$ & $\begin{array}{l}\text { Child (2005), Dutra (2009), Guimarães et al. (2013), Zaccarelli } \\
\text { et al. (2008), Castells (1999), Hitt Ireland and Hoskisson (2003), } \\
\text { Balestrin, Verschoore and Perucia (2011) }\end{array}$ \\
\hline Trust & $\mathrm{H} 2$ & $\begin{array}{l}\text { Mayer, Davis and Schoorman (1995), Child, Faulkner and } \\
\text { Tallman (2005), Klijn, Edelenbos and Steijn (2010), Zaheer, } \\
\text { McEvily and Perrone (1998), Claro and Claro (2004), Maciel, } \\
\text { Reinert and Camargo (2011) }\end{array}$ \\
\hline Internal Resources & $\mathrm{H} 3$ & $\begin{array}{l}\text { Barney (1991), Barney, Wright and Ketchen Jr. (2001), Gulati, } \\
\text { Nohria and Zaheer (2000), Roth et al. (2012), Carneiro, } \\
\text { Cavalcanti and Silva (1999), Balestrin, Verschoore and Perucia } \\
\text { (2011) }\end{array}$ \\
\hline $\begin{array}{l}\text { Performance of } \\
\text { Organizations }\end{array}$ & $\mathrm{H} 4$ & $\begin{array}{l}\text { Guimarães (2010), Fittipaldi and Donaire (2007), Zaccarelli et al. } \\
\text { (2008), Roth et al. (2012), Jones, Hersterly and Borgatti (1997), } \\
\text { Venkatraman and Ramanujam (1986) }\end{array}$ \\
\hline Network Governance & & $\begin{array}{l}\text { Roth et al. (2012), Jones, Hesterly and Borgatti (1997), Provan } \\
\text { and Kenis (2008), Zaccarelli et al. (2008), Guimaráes et al. } \\
\text { (2013), Ansell, Sondorp and Stevens (2012), Balestrin, Verschoore } \\
\text { and Perucia (2011) }\end{array}$ \\
\hline
\end{tabular}

Source: Prepared by the Author. 
From the theoretical exposition undertaken in the review of the literature, it is clear that Network Governance can be influenced by different factors that interfere directly in its execution, making the groupings more or less competitive.

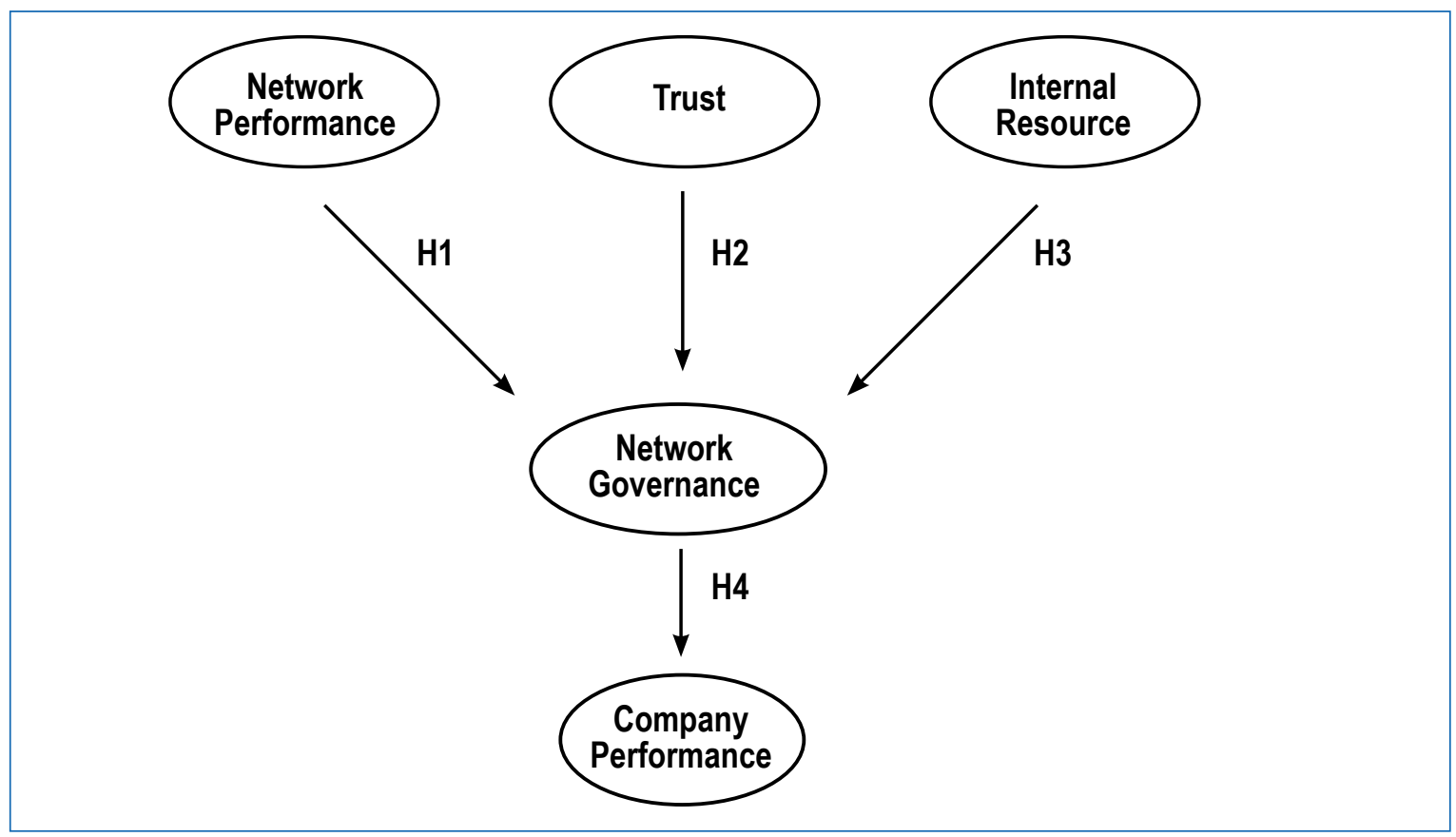

Figure 1. Hypothetical research model.

Source: Research data, 2016.

The hypotheses formulated for this research are the following:

- H1: Network Activities influence positively the construction of an effective networking governance.

- H2: Trust between the entities forming the network has a positive relationship with the effectiveness of the network governance.

- H3: The internal resources of the networking entity influence positively the effectiveness of the network governance.

- H4: An effective network governance contributes positively to increasing the performance of the companies in the group.

\section{METHODOLOGY}

The present research is of a quantitative nature, and a descriptive type, the survey method having been adopted where a structured questionnaire was applied by means of an electronic instrument and distributed during activities realized and/or supported by the Federation of Industries of the State of Minas Gerais.

At the stage of the application of the final research questionnaire, after a pre-test with eight companies, a non-probabilistic sampling for convenience was adopted, with a total of 181 respondents, in a questionnaire with 5 variables for the characterization of the interviewee and a further 28 questions on the object of the study, divided into the 5 constructs.

For the treatment of the data in this study, multivariate statistical analysis was utilized. The data collected, therefore, using the sampling obtained, was submitted to a statistical treatment 
by means of the modelling through the use of structural equations, via the PLS method (Partial Least Squares - Path Modeling), version 3.2.0. In addition, to compare the indices estimated by the structural model with the characterization variables, the Mann-Whitney and Kruskall-Wallis tests were utilized (Hollander, Wolfe, \& Chicken, 1999). The reliability of the constructs worked was measured by the utilization of the Cronbach Alpha (CA) and the Composite Reliability (CR) (Gosling \& Gonçalves, 2003).

For the description of the variables related to the profile of the interviewees, the calculation of absolute and relative frequencies was utilized. The presentation and comparison of the items of each construct was carried out utilizing the average and the bootstrap percentile interval of 95\% confidence, fixing the Likert scale with 5 points. To check the quality of the adjustments to the structural model, the $\mathrm{R}^{2}$ and the GoF were used (Amato et al., 2004).

To evaluate internal consistency (reliability) of the constructs, the Cronbach Alpha coefficient was used (CA) and Composite Reliability (CR), which are indicators based on the intercorrelation of the items of the construct, values above 0.70 being considered satisfactory and values above 0.60 acceptable in exploratory research. To evaluate the convergent validity, the criterion of Average Variance Extracted (AVE) was used, which measures the average percentage variability of the construct explained by indicator (dummy) variables (items). According to Hair et al., (2009), convergent validity is reached for AVE's greater than 0.50 with values above 0.40 being acceptable in exploratory research. Discriminant validity guarantees that the construct measured is empirically unique and was evaluated by means of the criterion proposed by Fornell and Larcker (1981), which suggests that the discriminant validity is reached if a determined construct presents an AVE greater than the variance shared with the other constructs.

The existence of two types of outliers was also checked: the univariate, that represent divergent replies based on each of the model's variables, and the multivariate, that represent a different reply pattern considering all the variables at the same time.

The reliability of the contracts considered was measured using the Cronbach Alpha (CA) and the Composite Reliability (CR). According to Tenenhaus et al. (2005), the CA and CR indicators should be greater than 0.70 to indicate reliability of the construct, values over 0.60 also being acceptable in exploratory research.

To calculate the reliability intervals for the weights of the measurement model and of the coefficients of the structural model, the Bootstrap method was used, supplying information about variability of the estimated parameters, furnishing, in this way, an important validation of the results.

For the preparation of this research, Structural Equation Modelling (SEM) was used that permits testing different hypotheses on the relations between latent and observed variables. The structural equation model is divided into two parts: the Measuring Model and the Structural Model.

The measuring model has the main objective of measuring the capacity of the set of indicators of each construct to represent its respective concept with precision. So to check the validity of the measuring model, the convergent and discriminant validities were assessed. The convergent evaluation criterion evaluates the degree to which two measures of the same concept are correlated, while the discriminant evaluation measures the degree to which a construct is truly different from the rest.

\subsection{The Federation of Industries of the State of Minas Gerais}

Founded on 12 February 1933 and recognized formally 10 years later, the FIEMG System is a high level Employers'Association entity, constituted for the purposes of coordinating, protecting and legally representing the economic categories belonging to the branches of industry, in the territory of the State of Minas Gerais, Brazil. 
With 60 years of experience and activity, the FIEMG System, through its five companies (FIEMG, CIEMG, SESI, SENAI, IEL), currently represents approximately 65 thousand industries, in addition to having 136 affiliated employers' associations, 10 regional units strategically positioned in the territory of the State of Minas Gerais, 11 thematic councils, 10 sectoral chambers and more than 200 operational units.

The System's mission is to lead the process of sustainable development of industry in Minas Gerais, working to make it increasingly competitive and innovative, and capable of generating new business, wealth and development. Thus the hope is that it will become an industry that stands out in Brazil and abroad, as well as a driver of economic and social growth of the whole state, promoting the continual improvement of socio-economic conditions therein, as well as for the country.

\section{ANALYSIS OF THE RESULTS OF THE RESEARCH}

\subsection{Characterization of the Companies and the Respondents}

The profile of the companies and the respondents can be described in the following way: almost half of those approached exercise managerial positions in their respective companies, $35.4 \%$ being partners and another $14 \%$ directors. Of the total, $49.1 \%$ of the companies have been acting with FIEMG for more than 5 years. In addition, $75.1 \%$ of the respondents stated that their companies were affiliated to some employers association (Table 1).

\subsection{Descriptive Analysis of the Construct Variables}

As has been presented in the methodology, the Likert scale was established to vary from -1 (Full Disagreement) to 1 (Full Agreement) so that average negative values will indicate a tendency to disagreement, while average positive values would indicate a tendency to agreement.

Table 1

Characterization of the Companies and the Respondents

\begin{tabular}{|c|c|c|c|}
\hline Variables & & $\mathrm{N}$ & $\%$ \\
\hline \multirow{4}{*}{ Position } & Partner & 63 & $34.80 \%$ \\
\hline & Director & 25 & $13.82 \%$ \\
\hline & Manager & 40 & $22.09 \%$ \\
\hline & Other & 53 & $29.29 \%$ \\
\hline \multirow{4}{*}{ Sector } & Food & 18 & $9.94 \%$ \\
\hline & Trade & 13 & $7.18 \%$ \\
\hline & Industry & 27 & $14.92 \%$ \\
\hline & Other & 123 & $67.96 \%$ \\
\hline \multirow{4}{*}{ Size of company } & Micro & 42 & $23.20 \%$ \\
\hline & Small & 59 & $35.59 \%$ \\
\hline & Medium & 41 & $22.65 \%$ \\
\hline & Large & 39 & $21.54 \%$ \\
\hline \multirow{2}{*}{ Affiliated to employers' association } & No & 45 & $24.86 \%$ \\
\hline & Yes & 136 & $75.14 \%$ \\
\hline \multirow{4}{*}{$\begin{array}{l}\text { Time that the company has been acting with } \\
\text { FIEMG }\end{array}$} & Up to 1 year & 28 & $15.46 \%$ \\
\hline & From 1 to 3 years & 35 & $19.34 \%$ \\
\hline & From 3 to 5 years & 24 & $13.26 \%$ \\
\hline & More than 5 years & 94 & $51.94 \%$ \\
\hline
\end{tabular}

Source: Research data. 
BBR

16

The construct trust was the construct with the highest indices of agreement on average, the statements CONF-1 (Trusting in FIEMG is important for my company`s activities) and CONF-4 (The relationship with FIEMG encourages openness, exchange of ideas and information), were those with the highest indices of acceptance with 65\% and 64\%, respectively.

The construct Network Performance presented its highest indices of agreement of $63 \%$ and $61 \%$ in the statements AR-1 (A close relationship to FIEMG has been important for my company) and AR-2 (FIEMG contributes to the promotion of integration between the companies that it represents), respectively.

The construct Internal Resources was that which represented the second highest average of agreement singling out the statements RI-1 (The technical body of FIEMG has the ability and helps aggregate knowledge to my company), with $61 \%$ of agreement, and RI-5 (The FIEMG physical structure offers benefits to its associates), which had $60 \%$ acceptance.

The construct Network Governance was that with the largest number of statements, 07 altogether, those questioned having a higher level of agreement with the statements relative to the contribution to competitiveness of the sectors caused by the influence exercised by the directors of FIEMG in the market. Also for the impartiality of the organization's activities, acting in the interests of all the industrial companies represented by it.

In relation to the construct Performance, in spite of it being that with the lowest indices, the statement DP-5 (Being linked to FIEMG gives my company a good reputation with the business community) presented an index of $57 \%$ agreement, which is considered high. Chart 2 presents the list of codes per item, as well as their respective constructs.

Chart 2

List of Codes per Item

\begin{tabular}{|c|c|c|}
\hline Construct & Item & Description \\
\hline \multirow{5}{*}{ Trust } & CONF-1 & Trusting in FIEMG is important for my company’s activities. \\
\hline & CONF-2 & I believe that FIEMG can help my company in unforeseen circumstances. \\
\hline & CONF-3 & FIEMG is an institution that does the right thing to help my company. \\
\hline & CONF-4 & $\begin{array}{l}\text { The relationship with FIEMG encourages openness, exchange of ideas and } \\
\text { information... }\end{array}$ \\
\hline & CONF-5 & $\begin{array}{l}\text { Being linked to FIEMG diminishes my perception of vulnerability in the } \\
\text { sector I am active in. }\end{array}$ \\
\hline \multirow{5}{*}{$\begin{array}{l}\text { Network } \\
\text { Performance }\end{array}$} & AR-1 & A close relationship to FIEMG has been important for my company. \\
\hline & AR-2 & $\begin{array}{l}\text { FIEMG contributes to the promotion of integration among the companies it } \\
\text { represents. }\end{array}$ \\
\hline & AR-3 & $\begin{array}{l}\text { The cooperation between companies via FIEMG permits the development of } \\
\text { resources... }\end{array}$ \\
\hline & AR-4 & $\begin{array}{l}\text { The relationship structure between the companies and FIEMG can be } \\
\text { considered a resource... }\end{array}$ \\
\hline & AR-5 & $\begin{array}{l}\text { FIEMG proportions adequate environments for increasing interaction } \\
\text { between the companies. }\end{array}$ \\
\hline
\end{tabular}


Cont.

\begin{tabular}{|c|c|c|}
\hline Construct & Item & Description \\
\hline \multirow{5}{*}{ Internal Resources } & RI-1 & $\begin{array}{l}\text { The technical body of FIEMG has the ability and helps aggregate knowledge } \\
\text { to my company. }\end{array}$ \\
\hline & RI-2 & $\begin{array}{l}\text { The FIEMG internal processes help my company to develop and access } \\
\text { external resources. }\end{array}$ \\
\hline & RI-3 & FIEMG collaborates to keep me updated in relation to the market. \\
\hline & RI-4 & $\begin{array}{l}\text { The technological resources of knowledge offered by FIEMG contribute to } \\
\text { improvement... }\end{array}$ \\
\hline & RI-5 & The physical structure of FIEMG offers benefits to its associates. \\
\hline \multirow{7}{*}{$\begin{array}{l}\text { Network } \\
\text { Governance }\end{array}$} & GSE-1 & $\begin{array}{l}\text { The leadership exercised by FIEMG contributes in some way to the } \\
\text { management of my company. }\end{array}$ \\
\hline & GSE-2 & $\begin{array}{l}\text { The directors of FIEMG are influential in the market and contribute to the } \\
\text { competitiveness of the sectors. }\end{array}$ \\
\hline & GSE-3 & $\begin{array}{l}\text { FIEMG acts impartially, representing the interests of all the industrial } \\
\text { companies... }\end{array}$ \\
\hline & GSE-4 & $\begin{array}{l}\text { FIEMG has the capacity to guide and influence the behaviour of the } \\
\text { companies represented by it. }\end{array}$ \\
\hline & GSE-5 & The FIEMG managerial processes are clear and productive. \\
\hline & GSE-6 & FIEMG possesses effective mechanisms for monitoring the sectors. \\
\hline & GSE-7 & The FIEMG managers transfer knowledge to my company. \\
\hline \multirow{6}{*}{ Performance } & DP-1 & I obtain higher profits through my relationship with FIEMG. \\
\hline & DP-2 & I become more competitive with the support of FIEMG. \\
\hline & DP-3 & $\begin{array}{l}\text { The performance and the results of the projects developed in my company } \\
\text { are noticeable... }\end{array}$ \\
\hline & DP-4 & $\begin{array}{l}\text { Aligning with the FIEMG orientations favours the attainment of the general } \\
\text { objectives of my... }\end{array}$ \\
\hline & DP-5 & $\begin{array}{l}\text { Being linked to FIEMG gives my company a good reputation with the } \\
\text { business community. }\end{array}$ \\
\hline & DP-6 & $\begin{array}{l}\text { With the support of FIEMG our company is undergoing a growth process in } \\
\text { market and products. }\end{array}$ \\
\hline
\end{tabular}

Source: Research data.

\subsection{Modelling Through the Use of Structural Equations}

In the analysis of the measuring model, we check: (i) convergent validity, which guarantees that the indicators of a construct are sufficiently correlated to measure the latent concept; (ii) the discriminant validity, which checks whether the constructs effectively measure different aspects of the phenomenon of interest; and (iii) the reliability of the constructs, which reveals the consistency of the measures in measuring the concept.

One can see in Table 2 the weights, the factor loads, and the commonalities of the measuring model presented in the research. It is stated that for a good measuring model, the factor loads (FL) should be greater than 0.70 , or the communality, greater than 0.40 ; however, items with factor loads less than 0.50 should be eliminated (Hair et al., 2009). In this manner, we should point out that: 1) all the items presented a factor load above $0.70 ; 2$ ) assessing the intervals of trust (I.C - 95\% - totally positive), one notes that all the weights were significant, which confirms the importance of all the items for the formation of the indicator that will represent the construct. 
BBR

16

444

Table 2

Crossed Factor Loads

\begin{tabular}{|c|c|c|c|c|c|c|}
\hline Constructo & Item & CONF & $\mathrm{AR}$ & RI & GSE & DP \\
\hline \multirow{5}{*}{ Trust } & CONF-1 & 0,886 & 0,691 & 0,719 & 0,682 & 0,638 \\
\hline & CONF-2 & 0,793 & 0,672 & 0,590 & 0,664 & 0,601 \\
\hline & CONF-3 & 0,849 & 0,725 & 0,724 & 0,655 & 0,609 \\
\hline & CONF-4 & 0,855 & 0,767 & 0,759 & 0,713 & 0,641 \\
\hline & CONF-5 & 0,747 & 0,583 & 0,528 & 0,565 & 0,563 \\
\hline \multirow{5}{*}{$\begin{array}{l}\text { Network } \\
\text { Performance }\end{array}$} & AR-1 & 0,785 & 0,847 & 0,796 & 0,719 & 0,711 \\
\hline & AR-2 & 0,739 & 0,880 & 0,731 & 0,708 & 0,614 \\
\hline & AR-3 & 0,636 & 0,828 & 0,686 & 0,636 & 0,574 \\
\hline & AR-4 & 0,658 & 0,773 & 0,661 & 0,591 & 0,527 \\
\hline & AR-5 & 0,673 & 0,862 & 0,760 & 0,675 & 0,564 \\
\hline \multirow{5}{*}{ Internal Resources } & RI-1 & 0,759 & 0,774 & 0,875 & 0,771 & 0,692 \\
\hline & RI-2 & 0,714 & 0,788 & 0,883 & 0,739 & 0,661 \\
\hline & RI-3 & 0,689 & 0,764 & 0,874 & 0,737 & 0,673 \\
\hline & RI-4 & 0,690 & 0,718 & 0,852 & 0,729 & 0,715 \\
\hline & RI-5 & 0,616 & 0,690 & 0,816 & 0,652 & 0,576 \\
\hline \multirow{7}{*}{$\begin{array}{l}\text { Network } \\
\text { Governance }\end{array}$} & GSE-1 & 0,692 & 0,693 & 0,756 & 0,801 & 0,758 \\
\hline & GSE-2 & 0,660 & 0,689 & 0,730 & 0,859 & 0,742 \\
\hline & GSE-3 & 0,724 & 0,692 & 0,720 & 0,883 & 0,704 \\
\hline & GSE-4 & 0,686 & 0,705 & 0,688 & 0,835 & 0,644 \\
\hline & GSE-5 & 0,707 & 0,666 & 0,735 & 0,880 & 0,735 \\
\hline & GSE-6 & 0,582 & 0,615 & 0,626 & 0,795 & 0,615 \\
\hline & GSE-7 & 0,630 & 0,631 & 0,718 & 0,842 & 0,758 \\
\hline \multirow{6}{*}{ Performance } & DP-1 & 0,605 & 0,560 & 0,598 & 0,713 & 0,867 \\
\hline & DP-2 & 0,670 & 0,653 & 0,719 & 0,755 & 0,906 \\
\hline & DP-3 & 0,618 & 0,612 & 0,690 & 0,766 & 0,923 \\
\hline & DP-4 & 0,706 & 0,675 & 0,716 & 0,769 & 0,905 \\
\hline & DP-5 & 0,657 & 0,670 & 0,710 & 0,739 & 0,809 \\
\hline & DP-6 & 0,673 & 0,639 & 0,675 & 0,739 & 0,911 \\
\hline
\end{tabular}

Source: Research data.

The reliability of the constructs worked was measured by means of the Cronbach Alpha (CA) and the Composite Reliability (CR). Following the proposal of Tenenhaus et al. (2005), in this research all the indicators $\mathrm{CA}$ and $\mathrm{CR}$ were greater than 0.70 indicating the reliability of the constructs. It should be further pointed out-that all the constructs were unidimensional, as they did not present any second eigenvalue greater than 1 and had AVEs greater than 0.5 , indicating convergent validation, as presented in Table 3. 
Table 3

Validation of the measuring model

\begin{tabular}{|c|c|c|c|c|c|c|c|c|c|c|}
\hline \multirow{2}{*}{ Constructos } & \multirow{2}{*}{ IteMs } & \multirow{2}{*}{ A.C. ${ }^{1}$} & \multirow{2}{*}{ C. $C^{2}$} & \multirow{2}{*}{$\begin{array}{c}1^{\circ} \\
\text { AV3 }\end{array}$} & \multirow{2}{*}{$\begin{array}{c}2^{\circ} \\
\mathrm{AV} 4\end{array}$} & \multirow{2}{*}{ AVE5 } & \multicolumn{4}{|c|}{ Shared Variances } \\
\hline & & & & & & & 1 & 2 & 3 & 4 \\
\hline 1 - Trust & 5 & 0,884 & 0,915 & 3,420 & 0,525 & 0,685 & & & & \\
\hline $\begin{array}{l}\text { 2- Network } \\
\text { Performance }\end{array}$ & 5 & 0,894 & 0,922 & 3,520 & 0,503 & 0,703 & 0,697 & & & \\
\hline $\begin{array}{l}\text { 3- Internal } \\
\text { Resources }\end{array}$ & 5 & 0,912 & 0,934 & 3,700 & 0,433 & 0,741 & 0,653 & 0,755 & & \\
\hline $\begin{array}{l}\text { 4- Network } \\
\text { Governance }\end{array}$ & 7 & 0,932 & 0,945 & 4,970 & 0,504 & 0,710 & 0,632 & 0,634 & 0,714 & \\
\hline 5-Performance & 6 & 0,946 & 0,957 & 4,730 & 0,514 & 0,788 & 0,546 & 0,513 & 0,598 & 0,709 \\
\hline
\end{tabular}

Note: ${ }^{1}$ Cronbach Alpha, ${ }^{2}$ Composite Reliability, ${ }^{3}$ First Eigenvalue, ${ }^{4}$ Second Eigenvalue, ${ }^{5}$ Variance Extracted.

Source: Research data.

To check the quality of the adjustments to the structural model, $\mathrm{R}^{2}$ and the GoF were utilized (Amato et al., 2004). $\mathrm{R}^{2}$ represents on a scale from $0 \%$ to $100 \%$ to what degree the independent constructs explain the dependent, the closer to $100 \%$ the better. The GoF is the geometric average of the average of the AVEs of the constructs and the average of the $\mathrm{R}^{2}$ of the model and also varies from $0 \%$ to $100 \%$ (Table 4 ).

The results obtained and presented in Table 4 revealed that:

\section{In relation to Network Governance:}

- There exists significant ( $\mathrm{p}$-value=0.000) and positive $(\beta=\mathbf{0 . 2 8 7}[0.17 ; 0.42])$ influence of Trust on Network Governance. The greater the Trust, the greater the Network Governance.

- There exists significant ( $\mathrm{p}$-value=0.000) and positive $(\beta=\mathbf{0 . 5 2 8}[0.33 ; 0.70])$ influence of Internal Resources on Network Governance. The greater the Internal Resources, the greater the Network Governance.

- There was no significant influence of Network Activities on Network Governance.

- The three indicators above can explain $75.3 \%$ of the variability of Network Governance.

\section{In relation to performance:}

- There exists significant ( $\mathrm{p}$-value=0.000) and positive $(\beta=\mathbf{0 . 8 4 2}[0.78 ; 0.90])$ influence of Network Governance on Performance. The greater the Network Governance, the greater the Performance.

Table 4

Structural Model

\begin{tabular}{llccccc}
\hline Endogenous & Exogenous & $\beta$ & I.C. - 95\% ${ }^{1}$ & E.P. $(\beta)^{2}$ & Value-P & $\mathrm{R}^{2}$ \\
\hline \multirow{3}{*}{ Network Governance } & Trust & 0,287 & {$[0,17 ; 0,42]$} & 0,071 & 0,000 & \\
& Network Perfoamce & 0,098 & {$[-0,08 ; 0,29]$} & 0,085 & 0,249 & $75,3 \%$ \\
& Internal Resources & 0,528 & {$[0,33 ; 0,70]$} & 0,079 & 0,000 & \\
Performance & Governance & 0,842 & {$[0,78 ; 0,90]$} & 0,040 & 0,000 & $70,9 \%$ \\
\hline
\end{tabular}

Note: ${ }^{1}$ Interval of Trust- Bootstrap Validation; ${ }^{2}$ Standard Error; GoF $=72.87 \%$.

Source: Research data. 
- The above indicator can explain $70.9 \%$ of the variability of Performance.

\section{It should be mentioned further that:}

- The model presented a GoF of $72.87 \%$.

- The intervals of trust via Bootstrap are in agreement with the results found by the p-value, indicating greater validity for the results presented.

Figure 2 is a representation of the results applied to the hypothetical model developed for this work.

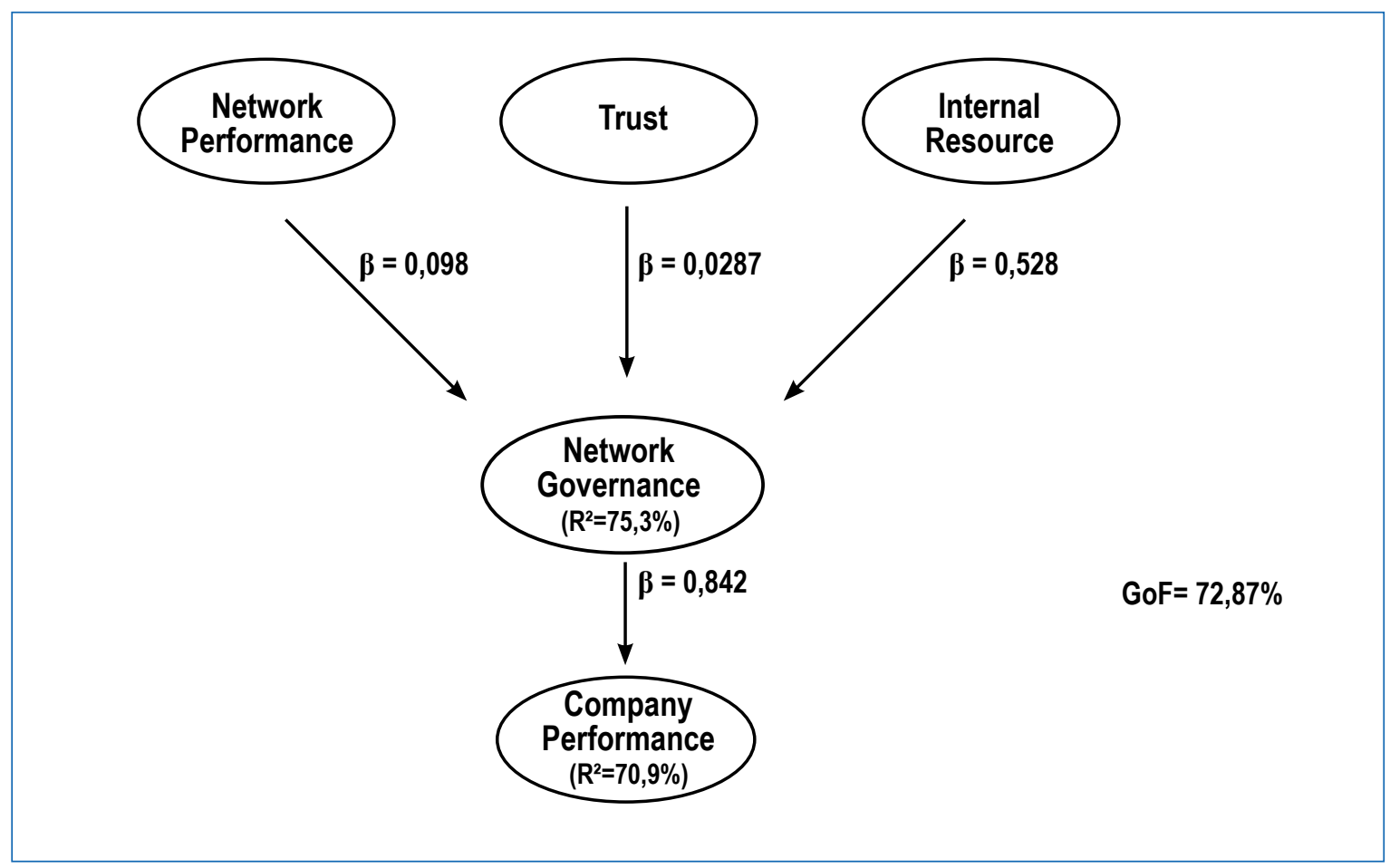

Figure 2. Illustration of the structural model.

Source: Research data.

In addition to the relations observed between the independent indicators (Exogenous) on the dependent (Endogenous), it was possible to check the direct and indirect effects of the relations among themselves. The following aspects are highlighted (Table 5):

- There was an indirect positive significant effect $(0.242[0.12 ; 0.35])$ of Trust on Performance;

- There was an indirect positive significant effect $(0.445[0.28 ; 0.60])$ of Internal Resources on Performance;

- There was no indirect significant effect of Network Activities on Performance. 
Table 5

Direct, Indirect, and Total Effects

\begin{tabular}{lcccc}
\hline Relations & Direct & Indirect & Total & I.C. - 95\%* \\
\hline Trust $\rightarrow$ Governance & 0,287 & - & 0,287 & {$[0,17 ; 0,42]$} \\
Trust $\rightarrow$ erformance & - & 0,242 & 0,242 & {$[0,12 ; 0,35]$} \\
Network Activities $\rightarrow$ Governance & 0,098 & - & 0,098 & {$[-0,08 ; 0,29]$} \\
Network Activities $\rightarrow$ Performance & - & 0,083 & 0,083 & {$[-0,08 ; 0,23]$} \\
Internal Resources $\rightarrow$ Governance & 0,528 & - & 0,528 & {$[0,33 ; 0,70]$} \\
Internal Resources $\rightarrow$ Performance & - & 0,445 & 0,445 & {$[0,28 ; 0,60]$} \\
Governance $\rightarrow$ Performance & 0,842 & - & 0,842 & {$[0,78 ; 0,90]$} \\
\hline
\end{tabular}

Note: *Bootstrap Interval of Trust.

Source: Research Data.

\section{ANALYSIS OF RESULTS}

Network Governance Entities (NGE) have started to play a central role in the operation of these groups, as they are capable of influencing behaviour and guiding strategy (Zaccarelli et al., 2008). Part also of their responsibility is the formulation of directives capable of maintaining the unity of the group so that, in this way, all members can continue to benefit from the advantages obtained (Guimarães, 2013). Nevertheless, as Jones, Hersterly and Borgatti (1997), point out, in spite of the NGE being recognized, the mechanisms that produce the alleged competitive advantages are still only vaguely defined.

The hypothetical model presented in Figure 1 was, therefore, created in which network governance can be explained by the constructs of network activities, internal resources and trust, a scenario that was confirmed when we obtained a value for R2 $=0.753$ for NGE, which demonstrates that the three constructs presented account for $75.3 \%$ of the variation of network governance.

Considering the effectiveness of the NGE, observing more deeply, the significant ( $\mathrm{p}$-value $=0.000)$ and positive influence of trust $(\beta=0.287[0.17 ; 0.42])$ and internal resources $(\beta=0.528[0.33 ; 0.70])$ on the NGE can be noted, in this way confirming hypothesis 2 , which proposes that trust among the bodies forming the network has a positive relationship with network governance - and hypothesis 3 that the internal resources of the network entity influence positively network governance. So, the greater and better the trust and internal resources, the better the NGE.

This result brings to the fore the fundamental importance of the role played by governance as an institution responsible for the monitoring of managerial behaviour, where trust becomes a key element in the reduction of conflict (Maciel, Reinert, \& Camargo 2011). Also, keeping in mind a systemic perspective of the grouping, the NGE has a fundamental role in the coordination of the grouping's resources as a source of competitive advantage to guarantee better performance than the competition (Carneiro, Cavalcanti, \& Silva, 1999).

On the other hand, that hypothesis 1 carries with it the idea that network performance influences the construction of effective network governance is not confirmed, as this construct does not present significant influence on network governance. In confronting the theories proposed on the theme, we have discovered that, even given the results obtained, network governance and network activities are constructs that should not be dissociated, as the characteristics and the objectives of the search for network performance can be considered central elements for the understanding of new forms of governance, as is the case of NG (Blanco, Lowndes, \& Pratchett, 2011). So that in spite of the non-significant influence of network activities on NG, one cannot 
conclude that the contrary is not true. Hypothesis 4 presented in this study relates NG to the performance of the companies involved, stating that network governance contributes positively to improving the performance of the companies in the grouping studied.

Considering the results obtained, this hypothesis was confirmed, confirming the presuppositions of the literature to the extent that significant $(p$-value $=0.000)$ and positive $(\beta=0.842[0.78 ; 0.90])$ influence was found. We should also mention that the construct Performance obtained a value for $\mathrm{R} 2=0.709$, which demonstrates that it represents $70.9 \%$ of the variability of Performance. In other words, it can be stated that the greater the Network Governance, the greater the Performance of the companies involved.

Thus, in considering company performance, it can be stated that the results are compatible with what the literature revealed on the theme, confirming the idea that good performance is associated with meeting the interests of the different groups related through the organization. (Santos, 2008; Cunha \& Corrêa, 2013), and which are in need of an effective system of governance to generate such relationship ties.

\section{FINAL CONSIDERATIONS}

The scenario of accelerated environmental transformation and the consequent need of organizations to adapt themselves to remain competitive is responsible for companies seeking new forms of activity, especially the role of NG.

Allied to the few theories that deal with the theme, the question has been suggested about the antecedents of the effectiveness of network governance and its influence on the performance of the companies involved, which culminated in a quantitative work of research undertaken with companies represented by the Federation of Minas Gerais.

Following this line of reasoning, the objective of this article was to evaluate the antecedents of the effectiveness of network governance of the Federation of Industries of the state of Minas Gerais and its influence on the performance of the group of companies involved. More specifically, the objectives were to check the influence of the antecedents of network activities, trust and internal resources on the effectiveness of network governance; and check the impact of network governance on the performance of the companies involved.

The choice of the Federation of Industries of the State of Minas Gerais for the analysis of this article is justified by the economic and social importance of this institution, as well as by the wide scope of its work, and by its decades-long experience and wide-ranging presence in the state of Minas Gerais.

As the objective drawn up for this study of "checking the influence of the antecedents on the NG" was reached, the three constructs considered as antecedents having explained $75.3 \%$ of the variability of Network Governance.

For the investigation undertaken in this study, in accordance with the theoretical framework presented, hypotheses were prepared to be tested with the support of statistical techniques and tools. The hypotheses formulated for this piece of research are the following: H1: network activities influence positively the construction of effective network governance. $\mathrm{H} 2$ : trust between the bodies forming the network has a positive relationship to the effectiveness of the network governance.H3: internal resources of the network entity influence positively the effectiveness of network governance. $\mathrm{H} 4$ : An effective network governance contributes positively to improve the performance of the companies in the grouping.

It should be mentioned that the statistical treatment proved significant ( $\mathrm{p}$-value $=0.000$ ) and positive $(\beta=0.287[0.17 ; 0.42])$ influence of trust and internal resources $(\beta=0.528[0.33 ; 0.70])$ on 
NG, confirming in this way hypotheses 2 and 3. This means that greater and better the confidence and internal resources, the more effective the NG. Hypothesis 1, on the other hand, was not confirmed, as network activities did not present significant influence on network governance.

Regarding the task of checking the impact of network governments on the performance, of the companies involved, the presupposition was adopted that the new forms of governance, like $\mathrm{NG}$, can be considered important elements for obtaining competitive advantages in the grouping. So that this objective was fulfilled as the existence was confirmed of significant ( $p$-value $=0.000$ ) and positive $(\beta=0.842[0.78 ; 0.90])$ influence of Network Governance on Performance, in other words, the greater the Network Governance, the greater the Performance, confirming Hypothesis 4 raised in this study. It should be mentioned further that the above indicator succeeds in explaining $70.9 \%$ of the variability of the Performance.

Figure 2 is the representation of the results applied to the hypothetical model developed for this work. From it the significant and non-significant relationships found are clear, in addition to contributing to the visualization of the verification or otherwise of the hypotheses raised, where $\mathrm{H} 2, \mathrm{H} 3$ and $\mathrm{H} 4$ were confirmed positive and, on the contrary, $\mathrm{H} 1$ was found not to be true.

In addition to the relationships observed between the independent indicators (Exogenous) and the dependent (Endogenous), it was possible to see the direct and indirect effects of the relationships between them. The following aspects should be mentioned:

- There was a significant positive indirect effect $(0.242[0.12 ; 0.35])$ of Trust on Performance;

- There was a significant positive indirect effect $(0.445[0.28 ; 0.60])$ of Internal Resources on Performance;

- There was no significant indirect effect of Network Activites on Performance.

In this study, we started from the presupposition that new forms of governance are considered indispensable elements for the success of networks in more advanced stages (Zaccarelli et al., 2008). In addition, competitive advantages obtained from this form of activity can only be observed from the moment where the network is capable of generating competitive resources for its associates that are difficult to imitate, by means of access to information, knowledge sharing and effective governance. (Dyer \& Singh, 1998; Balestrin, Verschoore, \& Perucia, 2011).

As this is a still recent theme, which presents few conceptual propositions and empirical causal relationships for the antecedents of network governance, both the model as the constructs and the questionnaire were developed and defined, but we stress that there may be other factors that influence the NG and that were not considered here. We point out, nevertheless, that in spite of the model being a proposition that still lacks other validations, it obtained a GoF of $72.87 \%$, which demonstrates its validity.

We believe that this research has contributed to refining the theoretical framework on NG, revealing new relationships and empirical proofs still little explored. In addition, we think the results obtained in this research make it possible to identify factors that should be considered by organizations interested in participating or creating network entities, contributing to effective governance of these groupings and, consequently, improving their performances.

So that in accepting the challenge of contributing to the theory of network governance, its antecedents and its influence on the performance of the companies involved, an attempt has been made to throw a light on the theme and encourage new researchers to continue the research process. Some variations of this study may be undertaken, especially considering that this study has only been carried out one network entity that contained a geographical limitation in its articles of incorporation resulting in the impossibility of generalising the results. Another 
point that could be tackled is the use of multi group analyses which could check, for example, respondent, influences the evaluation of the measuring model or if different sectors produce different performances.

It must be emphasized that many studies can still and should be undertaken to consolidate and clarify the theme of NG. Considering only the data already collected for this work, there is room for new multi-group analyses. Utilizing quantitative methods, one could check, for example, if the time of activity of the network entity or the respondent's position influences the evaluation of the measuring model or also whether different sectors result in different performances.

\section{REFERENCES}

Amato, S., Esposito Vinzi, V., \& Tenenhaus, M. (2004, March). A global goodness-of-fit index for PLS structural equation modelling (Vol. 24). Oral Communication to PLS Club. France: HEC School of Management.

Ansell, C., Sondorp, E., \& Stevens, R. H. (2012). The promise and challenge of global network governance: the global outbreak alert and response network. Global governance: a review of multilateralism and international organizations, 18(3), 317-337.

Astley, W. G. (1984). Toward an appreciation of collective strategy. Academy of Management Review, 9(3), 526-535.

Balestrin, A., Verschoore, J. R., \& Perucia, A. (2011). Visão relacional no campo da estratégia: evidências empíricas a partir das açóes coletivas de redes interorganizacionais. In V Encontro de Estudos em Estratégia. Porto Alegre.

Barney, J. B. (1991). Firm resources and sustained competitive advantage. Journal of Management, 17(1), 99-120.

Barney, J. B., Wright, Mike, \& Ketchen Jr., David. (2001). The resource-based view of the firm: Ten years after 1991. Journal of Management, 27(6), 625-641.

Blanco, I., Lowndes, V., \& Pratchett, L. (2011). Policy networks and governance networks: Towards greater conceptual clarity. Political Studies Review, 9(3), 297-308.

Boaventura, J. M. G., \& Siqueira, J. P. L. (2008). A estratégia e as redes de negócio. In X SEMEAD, Anais... São Paulo, FEA, USP. Retrieved from: http://www.infoteca.inf.br/contecsi/smarty/ templates/arquivos_template/upload_arquivos/acervo/docs/PDFs/118.pdf

Carneiro, J., Silva, J. F., Rocha, Â., \& Hemais, C. A. (2005). Mensuraçáo do desempenho organizacional: questóes conceituais e metodológicas. Estudos em negócios $I V$, 145-175.

Carneiro, J. M. T., Cavalcanti, M. A. F. D., \& Silva, J. F. da. (1999). Os determinantes da sustentabilidade da vantagem competitiva na visão resource-based. In ENCONTRO ANUAL DA ANPAD (23), Anais... Foz do Iguaçu: ANPAD.

Castells, M. (1999). A sociedade em rede (Vol. 1, 8a ed.). São Paulo: Paz e Terra.

Child, J. (2005). Organization: contemporary principles and practice. Birmingham: Blackwell Publishing.

Child, J., Faulkner, D., \& Tallman, S. B. (2005). Cooperative strategy. Oxford: Oxford University Press.

Claro, D. P., \& Claro, P. B. (2004). Gerenciando Relacionamentos Colaborativos com Fornecedores. Revista de Administração de Empresas, 44(4).

Cunha, J. A. C., \& Corrêa, H. L. (2013, Set./Out.). Avaliaçáo de desempenho organizacional: um estudo aplicado em hospitais filantrópicos. Revista de Administração de Empresas, São Paulo, 53(5), 485-499. 
Dyer, J., \& Singh, H. (1998) The relational view: cooperative strategy and sources of interorganizational competitive advantage. Academy of Management Review, 23(4), 660-679.

Dutra, I. (2009). Redes empresariais de negócios orientadas por estratégia definida pela governança supraempresas: estudo e metodologia de avaliação dos atributos componentes e respectivas influências sobre o poder da competitividade. (Tese de Doutorado). Universidade de São Paulo, São Paulo.

Ebers, M., \& Jarillo, J. C. (1997, Winter). The construction, forms, and consequences of industry networks. International Studies of Management \& Organization, 27(4), 3-21.

Fittipaldi, M. A., Donaire, D. (2007). Governança em redes de negócios: um estudo sob o enfoque da performance competitiva. In SEMEAD, Anais... São Paulo.

Fornell, C., \& Larcker, D. F. (1981). Evaluating structural equation models with unobservable variables and measurement error. Journal of Marketing Research, 39-50.

Gameiro, P. A. D. (2008). As organizaçóes em rede. Universidade Lusófona de Humanidades e Tecnologias. Retrieved from: http://www.bocc.ubi.pt/pag/gameiro-paulo-as-organizacoesem-rede.pdf

Gosling, M., \& Gonçalves, C. A. (2003, Ago./Dez.). Modelagem por equaçóes estruturais: conceitos e aplicaçôes. Revista de Administração FACES Journal, 2(2), 83-95.

Gulati, R. (1999). Network location and learning: The influence of network resources and firm capabilities on alliance formation. Strategic Management Journal, 20(5), 397-420.

Gulati, R., Nohria, N., \& Zaheer, A. (2000). Strategic Networks. Strategic Management Journal, 21(3), 203-215.

Guimarães, A. T. (2013). Empresas instaladas em entidades supra-empresas com orientação estratégica dual. Anápolis: Universidade Estadual de Goiás.

Guimarães, A. T., Almeida, F. A. S., Santos, S. A., \& Zaccarelli, S. B. (2007). Conceituando Entidades de Gestão Supra-Empresariais: Clusters e Redes de Negócios. In SEMEAD, Anais... São Paulo. Retrieved from: http://www.ead.fea.usp.br/semead/10semead/sistema/resultado/ trabalhosPDF/342.pdf

Hair, J. F., Black, W. C., Babin, B. J., Anderson, R. E., \& Tatham, R. L. (2009). Análise multivariada de dados. Porto Alegre: Bookman.

Hitt, M., Ireland, R. D., \& Hoskisson, R. (2003). Administração estratégica. São Paulo: Pioneira Thomson Learning.

Hollander, M., Wolfe, D., \& Chicken, E. (1999). The Two Sample Location Problem (3rd ed.). Nonparametric Statistical Methods.

Jones, C., Hesterly, W. S., \& Borgatti, S. P. (1997). A general theory of network governance: Exchange conditions and social mechanisms. Academy of Management Review, 22(4), 911-945.

Klijn, E. H., Edelenbos, J., \& Steijn, B. (2010, Apr.). Trust in governance networks; its impacts on outcomes. Administration \& Society, 42(2), 193-221.

Maciel, C. O., Reinert, M., \& Camargo, C. (2011, Aug.). Confiança e possibilidade de conflitos em redes estratégicas hierárquicas. RAM, Rev. Adm. Mackenzie (Online), 12(4), 182-208.

Martins, H. C., Hildebrand, D. F. N., \& Ziviani, F. (2008). Governança Corporativa: um estudo da produção científica da ANPAD no período de 2000 a 2007. In XXXII ENCONTRO DA ANPAD, Resumo dos Trabalhos do $31^{\circ}$ Encontro da ANPAD. Rio de Janeiro.

Mayer, R. C., Davis, J. H., \& Schoorman, F. David. (1995). An integrative model of organizational trust. Academy of Management Review, 20(3), 709-734.

Mcevily, B., Perrone, V., \& Zaheer, A. (2003). Trust as an organizing principle. Organization Science, 14(1), 91-103.

Miles, R. E., \& Snow, C. (1986, Spring). Network Organizations: new concepts for new forms. California Management Review, 28(3), 62-73. 
BBR

16

Morgan, R., \& Hunt, S. (1994, July). The Commitment-Trust Theory of Relationship Marketing. Journal of Marketing, 58, 20-38.

Provan, K. G., \& Kenis, P. (2008). Modes of network governance: Structure, management, and effectiveness. Journal of Public Administration Research and Theory, 18(2), 229-252.

Ricci, G. L. (2010). Desempenho e controle em pequenas e médias empresas. Estudo do setor hoteleiro da regiáo central do estado de São Paulo (Tese de Doutorado em Engenharia de Produção). Escola de Engenharia de São Carlos da USP, São Carlos.

Roth, A. L., Wegner, D., Antunes Júnior, J. A. V., \& Padula, A. D. (2012). Diferenças e interrelaçóes dos conceitos de governança e gestão de redes horizontais de empresas: contribuiçóes para o campo de estudos. Revista de Administração da Universidade de Sáo Paulo - RAUSP, $47(1), 112-123$.

Santos, J. B. (2008). Uma proposta de conceituação e representação do desempenho empresarial, Dissertação (Mestrado em Administração de Empresas). Escola de Administração de Empresas, Fundação Getúlio Vargas, São Paulo.

Telles, R. (2008). Clusters e redes de negócios. Curitiba: IESDE Brasil.

Tenenhaus, M., Vinzi, V., Chatelin, Y., \& Lauro, C. (2005). PLS path modeling. Computational statistics \& data analysis, 48(1), 159-205.

Venkatraman, N., \& Ramanujam, V. (1986). Measurement of Business Performance in Strategy Research: A Comparison of Approaches. Academy of Management Review, 11(4), 801-814.

Wernerfelt, B. (1984). A resource-based view of the firm. Strategic management journal, 5(2), 171-180.

Williamson, O. (1991, Jun.). Comparative economic organization: The analysis of discrete structural alternatives. Administrative Science Quarterly, 36(2), 269-296.

Zaccarelli, S. B., Guimarães, A. T., Almeida, M. I., \& Almeida, F. A. S. (2007). Conceituando Clusters de Negócios como Entidade Supra-Empresas. In SEMEAD, Anais... São Paulo.

Zaccarelli, S. B., Telles, R., Siqueira, J. P. L., Boaventura, J. M. G., \& Donaire, D. (2008). Clusters e redes de negócios: uma nova visão para a gestão dos negócios. São Paulo: Atlas.

Zaheer, A., Mcevily, B., \& Perrone, V. (2003, Mar./Abr.). Does trust matter? Exploring the effects of interorganizational and interpersonal trust on performance. Organization science, 9(2), 141-159. 